\title{
The Implementation of E-Budgeting Policy in Regional Government (A Case Study in Jakarta Province Province)
}

\author{
Ondy Asep, SAPUTRA,
}

Doctoral Student Administrative Sciences, Faculty of Administrative Studies, Brawijaya University, Malang, East Java, Indonesia ondyasep@gmail.com

Abdul, HAKIM,

Department of Public Administrative Science, Faculty of Administrative Science, Brawijaya University, Malang, East Java, Indonesia abdulhakim@ub.ac.id

Choirul, SALEH,

Department of Public Administrative Science, Faculty of Administrative Science, Brawijaya University, Malang, East Java, Indonesia choirulsaleh@ub.ac.id

Ratih Nur, PRATIWI,

Department of Public Administrative Science, Faculty of Administrative Science, Brawijaya University, Malang, East Java, Indonesia ratihnp@yahoo.com

\begin{abstract}
This research was conducted using the qualitative method so that the researcher can thoroughly and comprehensively elaborate on the phenomenon being studied. The research was focused on the process of e-Budgeting policy implementation in the government of Jakarta Province, as well as the supporting and obstacle factors of the process of e-Budgeting policy implementation in the Government of Jakarta Province. The process of e-Budgeting policy implementation is a part of the process of budget planning in the Regional Revenue and Expenditure Budget, therefore, the implementation process follows the APBD budgeting, which is started from the preparation of the General Budget Policies and Provisional Budget Ceiling and Priorities to the stipulation of the APBD. The implementation of the e-Budgeting policy is conducted to facilitate the effective and efficient establishment of APBD. The effectiveness of the e-budgeting policy implementation is influenced by the human resources capacity in the mastery of information and communication technology, budgeting politics, and the opposing interests of the executives and legislatures. The supporting and obstacle factors of the process of e-Budgeting policy implementation are in the factors of commitment and executives' interests, coordination and communication between the executives and legislatures, competence and commitment of the legislatures, coordination and competence of the OPD, as well as the factor of law. Additionally, the allocation of budget by the executives in the discussion of RAPBD, beside the inadequate planning in the initial preparation, there are also attempts to prioritize interests. Meanwhile, the issues in the SKPD in planning the budget based on working achievements, as mandated in the RKA-SKPD, is actually still related to the competence of the SKPD.
\end{abstract}

Keywords: Policy implementation, E-budgeting, Regional government.

JEL Classification: D8, D82, H1, H11. 


\section{Introduction}

The e-Budgeting policy emerged with an objective to provide a solution over public demand on accurate and accessible budgeting for the public through technology. The working method of the system is aimed and beneficial to remove the APBD stealth budget. The e-Budgeting system implemented is unchangeable, even the Regional Financial Management Board (BPKD - Badan Pengelola Keuangan Daerah) does not know how to create and apply it because it has been locked. The e-Budgeting system will keep the program activities that have been constructed by the Local Government Working Unit (SKPD - Satuan Kerja Pemerintah Daerah) is not approved by the Regional People's Representative Council (DPRD - Dewan Perwakilan Rakyat Daerah). However, it is admitted as a breakthrough in regional financial policy, the utilization of e-Budgeting still has flaws, which is related to the vulnerable system against hackers or online virus that can damage the data.

The effectiveness and efficiency of the budgeting process through the implementation of the e-Budgeting system is also are also supported by multiple studies, including the research findings by Nugraheni (2015) which analyzed the process of e-Budgeting planning upon the efficiency of APBD realization of 2015 budget in Indonesia. This research shows the effectiveness of e-Budgeting roles in the process of budget planning and also helping to make the APBD realization by creating budget activities process efficient, started from the planning, budgeting, up to budget controlling to be faster and cost less in order to achieve budget realization. Similarly, in the research findings of EPRS, European Parliamentary Research Service (2015), it is stated that the process of governance implementation will be more transparent and accountable with the implementation of e-Budgeting. A similar idea is also shown in the research findings by Kusumo et al., (2016), that the implementation of e-Budgeting in regional governance has helped and facilitated the data process of the Preparation of Budget and Work Plans of Local Government Working Units (RKA-SKPD Pedoman Penyusunan Rencana Kerja dan Anggaran Satuan Kerja Perangkat Daerah) into a proper and valid budget submission document to support the managerial decision in the preparation of the Regional Revenue and Expenditure Budget (APBD - Anggaran Belanja dan Pendapatan Daerah).

In order to actualize the good governance, the Regional Government of Jakarta Province has been implementing e-Budgeting system since 2013, which was a extension of the implementation of Presidential Instruction No. 3 of 2003 regarding National Policy and Strategy of e-Government Development which was 
aimed to create a governance that is clean, transparent, accountable, and free of corruption and collusion toward the budget of the Jakarta Province Provincial Government in the future. The policy is regulated through the Governor of Jakarta Province Regulation No. 145 of 2013 regarding Preparation of Planning of Regional Revenue and Expenditure Budget / Regional Revenue and Expenditure Budget Changes through Electronic Budgeting. However, there is still a number of normative problems including the absence of uniformity in the stakeholders' vision in the implementation of the Governor Regulation, which can be seen from the "conflict" between the executives and legislatures in the implementation process.

Besides normative problems, there is also an empirical issue related to the e-Budgeting implementation which is considered not optimal. As stated by the Governor of DKI, Basuki Tjahaja Purnama, the implementation of electronic budgeting system has not been optimally implemented by a number of SKPD of DKI Provincial Government. This is based on the findings in the budget proposal of the General Budget Policies and Provisional Budget Ceiling and Priorities (KUAPPAS - Kebijakan Umum Anggaran dan Plafon Prioritas Anggaran Sementara) for the 2016 APBD in a number of SKPDs (Okezone News, 2015).

Yet, the issues that occurred were on how the actors' implementation and roles, model of e-Budgeting implementation, and existing mechanism have not aligned with the public demands. This intrigues the researcher to conduct this research on the implementation of Presidential Instruction No. 3 of 2003 which is actualized in a form of e-Budgeting by the Daerah Khusus Istimewa (DKI) Jakarta Regional Government. Besides, there is a disagreement between the DKI Provincial Government and DKI DPRD regarding the implementation of eBudgeting, which became the empirical problematic related to the importance of this research. It is caused by the polemic between the Jakarta Province Regional People's Representative Council and the Governor of Jakarta Province, Basuki Tjahaja Purnama a.k.a Ahok (Erianto, 2015).

As stated by Erianto (2015), the polemic started from the Jakarta Province APBD proposal through electronic budgeting by Ahok to the Ministry of Home Affairs after authorized together with the DPRD of Jakarta Province. Yet, the APBD proposed by the Jakarta Province Provincial Government, which did not have the DPRD's signature of approval, was returned by the Ministry of Home Affairs. The DPRD of Jakarta Province considered that the e-Budgeting budget proposal was invalid and proposed the DPRD version of APBD Budget. In relation to Ahok's decision to submit the e-budgeting APBD to the Ministry of Home Affairs, the DPRD of Jakarta Province decided to exercise its inquiry rights. On another side, 
Ahok responded to the inquiry rights by reporting a finding of stealth fund of $\mathrm{Rp}$. 12,1 trillion to the Commission of Corruption Eradication (KPK).

One part of e-government is e-Budgeting policy as a facility to improve the service quality of public budget, increase transparency, make the administrative cost-efficient, and also empower the parties involved as a user in the utilization of e-Budgeting so that it is actualized an accountable governance in the budget implementation and avoiding corruption, collusion, and nepotism practices, both in the executives and legislatures. e-Budgeting is a financial system that is kept online with an objective of transparency for all parties. This system is implemented as documentation of budget planning in a region. Every individual can access the budget data compiled by a regional government so that it is expected to be able to prevent any attempt of embezzlement or bureaucratic fraud. In Uangteman Blog (2016), it is mentioned some strengths of e-budgeting compared to conventional financial documentation, including:

(1) preventing corruption practices through attempts of prevention of financial data manipulation because the data that has been inputted cannot be changed as it is already distributed to the public;

(2) the presence of public transparency principle, because financial data can be monitored and controlled by the public by submitting complaints in case there are suspicious data;

(3) the existence of financial data collection efficiency, because of the use of the integrated system and network, the regional government can control and evaluate directly while simultaneously the public can take an active role in monitoring the data that has been stored online.

Therefore, e-Budgeting provides a solution over public demand on accurate and accessible budgeting for the public through technology. The working method of the system is aimed and beneficial to remove the APBD stealth budget. The e-Budgeting system implemented is unchangeable, even the Regional Financial Management Board (BPKD - Badan Pengelola Keuangan Daerah) does not know how to create and apply it because it has been locked. The e-Budgeting system will keep the program activities that have been constructed by the Local Government Working Unit (SKPD - Satuan Kerja Pemerintah Daerah) is not approved by the Regional People's Representative Council (DPRD - Dewan Perwakilan Rakyat Daerah). However, it is admitted as a breakthrough in regional financial policy, the utilization of e-Budgeting still has flaws, which is related to the vulnerable system against hackers or online virus that can damage the data. 


\section{Theoretical Review}

\subsection{Public Policy}

The term policy is often used interchangeably with the term goals, program, decision, regulation, conditions, ideas, and big plannings (Abdul Wahab, 1997:2). The United Nations (1975) defined policy as a declaration of a guideline to act, direction of a certain act, a program regarding certain activities or certain planning, a program regarding certain activities or certain planning (Abdul Wahab, 1997:2). The policy essentially is a guideline to act. This guideline may be very simple or complex, general or specific, wide or narrow, abstract or exact, loose or detailed, qualitative or quantitative, and public or private. In line with the definition of policy as stated by the United Nations, Fredrick (in Islamy, 1997:17) defined policy as "... a set of acts proposed by an individual, group or government within a certain environment by showing the obstacles and opportunities toward the implementation of the policy proposal in order to achieve certain goals".

Another definition was stated by Anderson (in Islamy, 1997:17), in which a policy is "A purposive course of action followed by action or a set of actors in dealing with a problem or matter of concern".

The last definition was stated by Easton (in Abdul Wahab, 1989:21), who briefly stated that a policy is "A policy ... consist of a web of decisions and actions than allocate.....values".

Other than the three definitions above, truly there are more of other definitions of it, yet, among all, apparently, there is no striking difference of perspective in interpreting certain policies. From the three opinions regarding the meaning of policy, essentially, every formulation has several elements, such as: (1) a set of actions; (2) conducted by individuals or groups; (3) problem-solving; and (4) certain goals.

If the four elements are combined, it can be acquired a definition that a policy is a set of actions comprise of decisions followed and implemented by an individual or group in order to solve a problem thus achieving certain goals.

Even though the term can be done generally, in reality it is more often and widely used in relation to government actions or practices, as well as state behavior in general, which is more known as public policy. The definition of public policy varied based on experts who defined it similarly to the definition of the policy itself. The following can only be stated some of them, such as the one stated 
by Dye (in Islamy, 1997:18), that public policy as "is whatever government choose to do or not to do". Furthermore, Dye argued that if the government chooses to do something, then it must have an objective. Public policy must include the government's actions so that it is not merely a statement of the will of the government or government officials. Besides, something that is not implemented by the government is also categorized as public policy. This is because 'something that is not conducted' by the government will have an influence as big as 'something conducted' by the government.

An argument, similar to Dye, was argued by Edwards and Sharkansky (in Islamy, 1997:18) in which, "... is what government say and do, or not do. It is the goals or purposes of government programs ...". Additionally, Anderson (1979:3) stated that "public policies are those developed by government bodies and officials". And lastly, argued by Jenkins (in Abdul Wahab, 1997:4) that a public policy is "A set of interrelated decisions taken by a political actor or group of actor concerning the selection of goals and the means of achieving them within a specified situation where these decisions should, in principle, be within the power of these actors to achieve".

Among the definitions of public policy mentioned above, Islamy (1997:20) argued that the important elements of public policy include:

a. That public policy, in its initial form, is a stipulation of government actions;

b. That public policy is not enough only by statements but also implemented in a concrete form;

c. That a good public policy to do or not do something has and based upon certain intentions and objectives;

d. That public policy must always be intended to the public interests.

\subsection{Policy Implementation}

Implementation as a process to actualize the objectives of the policy is often known as a critical stage because this stage is a connector between the world of concept and world of reality. As argued by Grindle (1980:6), implementation "establish a link that allows goals of public policies to be realized as outcomes of governmental activity". The world of concept referred here is reflected in the ideal condition, something desired to be actualized as formulated in the policy documents. Meanwhile, the world of reality is the reality wherein the public as the target group faces a variety of social, economic, and political issues. 
Policy implementation which becomes a connector between ideal world and real world must be followed up by real action as argued by Van Meter and Van Horn (1975), that: "Policy implementation is actions conducted either by government or private individuals or officials or groups which are directed to the accomplishment of objectives that are determined in the policy decision". This statement aligns with that of Edwards III (1980) that stated: "policy implementation...is the stage of policymaking between the establishment of a policy ... and the consequences of the policy for the people whom it's affect". That policy implementation is a stage of policy process between the existing policy and its consequence toward the public, which is affected by the policy.

The public affected by the policy can be seen from the public policy programs, as stated by Grindle (1980), "the measurement of implementation success can be seen from its process by questioning whether the program implementation is in accordance with the pre-determined ones, which is looking at the action program of individual projects and whether the program's objectives are accomplished". Grindle's argument aligns with that of Lester and Stewart (2000), which argued that: "Implementation as a process and output. The success of policy implementation can be measured or seen from the process and accomplishment of output, which is whether the objectives are accomplished or not".

The implementation process begins with the existence of a policy or program. In order to achieve the objectives, a policy requires policy input that will be processed or converted into policy output.

A policy output will not reach the targeted group without activities to convey the policy output in a form of activities realization. The activities of conveying the policy output become the duties of implementing agency or implementor as stated by Smith. In the past, the primary implementing agency is the government or executive bureaucracy. Nowadays, the implementing agency is no longer the government's monopoly. Other than because of the government's limited ability in terms of budget, human resources, technology, and management capacity to solve all public affairs. Democracy demands the government to be more open and inclusive in providing space for the Civil Society Organization (CSOs) and private sector to be involved in the policy implementation. 


\subsection{Regional Government}

Historically, the origin of the current regional government structure is rooted in the 11th and 12th century Europe. Some terms used for Regional Government derived from Greek and ancient Latin, Koinates (community) and Demos (district people) are terms of regional government used in Greece heretofore.

In its development, the Regional Government is then perceived as a government organizational unit based on certain geography within a sovereign state. This type of governance is categorized as an intermediary unit, such as a province, a foundational unit, such as a city, municipality, or county or regency, and in several countries, sub municipal (Sarundajang, 2001: 24).

According to Stoker (1991), the emergence of modern regional government is closely related to the phenomenon of industrialization that happened in England in the mid 18th century. The industrialization caused a major migration from villages to cities. The urbanization constituted a shift in the regional features. There occurred new regions especially in cities and outskirts that were traditional with urban characteristics. the condition created new issues in the field of social, politics, and law. Therefore, in order to respond, it was required to rearrange the social system that regulates the shifted public interests. In order to respond to the condition, initially, it was formed ad hoc agencies to cope with issues that were still being controlled by the central government. In the following development, in a unit of local administration, it was formed a City Board elected by the locals. The City Board was given the authority to regulate and manage its own affairs. Here it was developed regional government practices as of today.

\subsection{Public Sector Budget}

Generally, public budget is defined as planning that depicts the amount of money received and spent (regional and state budget). This definition based on that budget is a tool and medium for the government to establish public lives to the creation of a better life in the future (Jamaludin, 1982:15). Another definition stated that public sector budget is a document that depicts the financial condition of an organization, which includes information regarding the revenue, expenditure, and activities. Briefly, it can be assumed that public budget is a financial planning that states: (a) the cost of the plan (expenditure); and (b) the amount of funding on how to acquire capital to fund the planning (revenue) (Chaniago, 2015). 
Furthermore, Elmil (2002) argued that budgeting is a process of financial planning preparation including the income and financing, followed by fund allocation to each activity in accordance with the function and target to be achieved. Each activity is then categorized into programs based on the tasks and responsibilities of certain units. The working units refer to implementing organizations, such as departments, offices, and technical institutions. In this case, the APBD as an annual regional financial planning is determined based on the regional regulation on the Regional Revenue and Expenditure Budget. Thus, APBD is a budgeting model of regional government that is approved by the legislatures, executives, and public.

There are six main functions of public sector budget, according to Chaniago (2015), as explained below.

(1) Budget as a planning tool. Budget is a tool of management planning to achieve organizational objectives. As a planning tool, a budget is used for: (a) formulate the objectives and target of the policy to be suitable to the determined vision and mission; (b) plan many programs and activities to achieve the organization's objectives and plan the alternative financing sources; (c) allocate funding to many programs and activities that have been arranged; and (d) determine indicators of performance and level of strategy achievement.

(2) Budget as a control tool. As an instrument of control, a budget is used to avoid overspending, underspending, and misappropriation in the budget allocation to other sectors that are not a priority. The control of public budget can be conducted through four methods, including: (a) comparing actual performance and budgeted performance; (b) calculating the budget gap (favorable and unfavorable variances); (c) identifying the controllable and uncontrollable causes of a variance; and (d) revising the standard of cost or budget target for the following year.

(3) Budget as a fiscal tool. In this context, a budget is used to stabilize the economy and encourage economic growth. Through the public budget, it can be acknowledged the direction of the government fiscal policy, therefore, it can be made an economic prediction and estimation.

(4) Budget as a political tool. Budget is used to decide the priority and financial need over the priority itself. In the public sector, budget is a political document as a form of executives and legislatures' commitment upon the use of the public fund for certain interests. 
(5) Budget as a coordination and communication tool. It means, becoming a tool to conduct coordination and communication among working units within an organization at a government environment.

(6) Budget as a performance measurement tool. A budget is a form of commitment and budget holder (executives) toward the authority (legislatures). The executives' performance will be assessed based on the achievement of budget target and efficiency of budget implementation.

\section{Research Method}

This research examines the process of e-Budgeting policy implementation and the factors that support and hamper the process of the e-Budgeting policy implementation in the Jakarta Province Government, holistically, through the description in a form of words and language (not quantitative description) and analyzed inductively by comparing relevant theories (Moleong, 2008:6).

The overall aspect becomes the study in this dissertation research, through the qualitative approach, it is hoped that the researcher is able to depict thoroughly and comprehensively the phenomenon being studied as elaborated in the research focus, therefore, eventually, it can answer the research questions that have been formulated, thus, the research objectives can be achieved.

The collected data were tested for its validity and reliability using the tests of credibility (internal validity), transferability (external validity), dependability (reliability), and confirmability (objectivity). Furthermore, the data were then analyzed using the Interactive Model method (Miles, et al., 2014), with the components of analysis data comprise of data collection, data condensation, data display, and conclusion. The interactive model in the data analysis is shown in the following picture.

Figure 1. Components of Data Analysis: Interactive Model

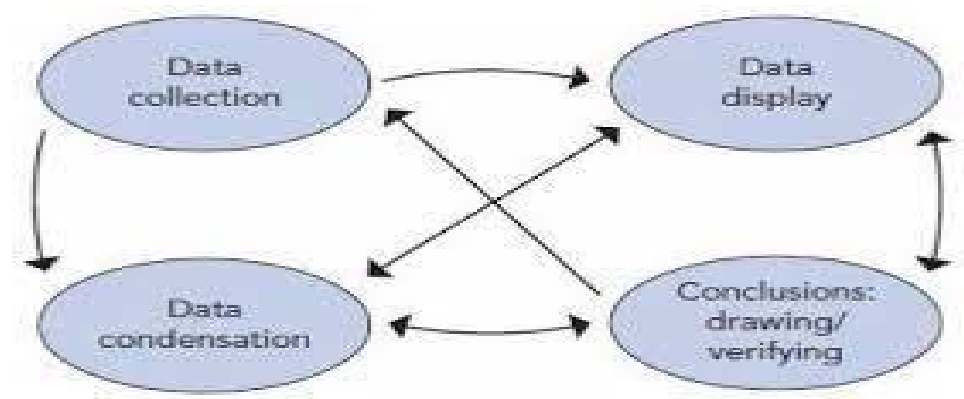


Source: Matthew B. Miles, et al., Qualitative Data Analysis: A Methods Sourcebook. Singapore:

SAGE Publications Inc., 2014:33.

4. Results and Discussions

4.1. The Process of e-Budgeting Policy Implementation in the Jakarta Province Government

The research findings show that the preparation of e-Budgeting in the budgeting practices in the Jakarta Province Provincial Government has helped to make the APBD realization efficient by making the process of budgeting activities faster and reducing the cost spent by the Jakarta Province Provincial Government in achieving the budget realization. The entire data from the proposal stage up to the end of the budget year had been integrated and stored well, therefore, if needed, the search for the budget origin and its implementation can be done quickly through the e-Budgeting system.

As explained in the previous chapter that the guideline and format of general budget policy formulation have been stipulated by the government, in this case, the Ministry of Home Affairs, which was written in the Minister of Home Affairs Regulation No. 13 of 2006 regarding Guideline of Regional Financial management. In light of this, the guideline of APBD drafting, third part of public policy and provisional budget ceiling and priorities, article 83 to 86 which essentially contains the regulation of the mechanism of the APBD public policy drafting and stipulation. This regulation puts an emphasis on foundation of the APBD public policy that must be started with a community aspiration screening activity, either by the regional government or the DPRD, as well as referring to the regional strategic planning and other planning documents that have been determined and is oriented to the points of national agendas related to the field of regional financial by the Minister of Home Affairs.

From the normative aspects, it can be seen that the interaction between the executives and legislatures to stipulate a general budget policy (KUA - Kebijakan Umum Anggaran) cannot be separated from external factors that are monitored through this research, including regional public aspirations, regional planning policy, and national policy.

The general budget policy, KUA hereafter, of the 2017 APBD is a form of budget policy formulation that became the foundation of budget operational planning in the framework of regional budgeting. The government decision based 
on the Minister of Home Affairs Regulation No. 13/2006, specifically article 85 and 86, explains that the draft of General Budget Policies (KUA) that has been composed by the Regional Secretary as the coordinator of financial manager was stated by the district head at the latest of early June of the on-going budget year. Meanwhile, the district head's delivery to the DPRD to be discussed is at the latest of late June of the on-going budget year. The KUA draft that has been discussed and approved becomes a KUA by the DPRD budgeting committee with the team of Regional Budget Committee (TPAD - tim Panitia Anggaran Daerah) at the latest of the first week of June of the on-going budget year.

In its implementation, the Year APBD planning in Jakarta Province province had a shift wherein the head of DPRD of Jakarta Province province issued a schedule of 30 to 4th of June 2017. After conducting a discussion toward the 2017 KUA by the DPRD Budgetary Body and team of Regional Budget Committee (TPAD) of Jakarta Province Province for 7 days, which, in the discussion, it was agreed that the result of the development planning forum that was accommodated by the respective SKPD in accordance with the main duties and functions that are written in a format of program document of Jakarta Province Provincial Government of 2017 and the results of recess that was conducted by the DPRD 3 times within a year, which will become the foundation of comparative planning in the productive and transparent budget planning. The result of discussion at the first level is agreed and it was stipulated the General Budget Policy (KUA) of the revenue of Jakarta Province provincial expenditure in 2017 budget year, with No: 904/523 of 2014 and No: 170/03 of 2014. With the stipulation of the KUA, it then became the foundation of the arrangement of Provisional Budget Ceiling and Priorities (PPAS) of the APBD of Jakarta Province Province Budget Year of 2017 (Source: Bappeda Jakarta Province, 2017).

As described above that the mechanism of determination of Provisional Budget Ceiling and Priorities (PPAS) of the APBD of Jakarta Province Province must be initiated with a draft formulation of the Provisional Budget Ceiling and Priorities (PPAS) by the Team of Regional Government Budget (TPAD) of Jakarta Province Province. The process of PPAS formulation is a form of implementation of article 34 paragraph (1); Government Regulation No. 58 of 2005 and article 83 paragraph (1) Minister of Home Affairs Regulation No. 59 of 2007 which mandate that district head forms KUA and PPAS drafts based on the RKPD and APBD drafting guideline stipulated by the Minister of Home Affairs each year.

As one of the annual planning documents, PPAS is drafted based on the RKPD and is an embodiment of General Budget Policies (KUA) which refers to other development planning documents which were determined by the regions and 
oriented to many applicable regulations and rules. The Government Regulation No. 58 of 2005 regarding Regional Financial Management explained that the PPAS is a program of priority and a guideline of maximum budget limit given to the SKPD for every program as a reference in drafting the RKA-SKPD. Furthermore, in article 86 of Minister of Home Affairs Regulation No. 59 of 2007, it is mandated that the PPAS planning is drafted through the following steps: (a) determining the priority scale of regional development; (b) determining the program priority for every affair; and (c) drafting a provisional budget ceiling for every program/activity.

The drafting of 2017 PPAS contained planning of revenue and receipt of regional financing of 2017 Budget Year, priorities of regional expenditure, provisional budget ceiling for each activity and SKPD, provisional budget ceiling for programs and activities, provisional budget ceiling for indirect expenditure, and regional expenditure plans of 2017 Budget Year. The draft of PPAS, which is the foundation to plan the Regional Revenue and Expenditure Budget Plans (RAPBD Rancangan Anggaran Pendapatan dan Belanja Daerah), has functions to: (a) be a reference for all development actors because it contains programs and activities that lead to public services; (b) be a guideline of APBD drafting because it contains priorities of development programs and activities for one budget year; and (c) create policy certainty because it is a commitment of regional government.

The main objective of the drafting of the Provisional Budget Ceiling and Priorities (PPAS) of Jakarta Province Province Year 2017 is to synchronize and harmonize the program and activity targets through government policies in the field of state financial and maintain the sustainability of the organization of governance, regional development, as well as public services. The process of budget formulation authority conducted by the Jakarta Province Provincial Government is to interpret the General Budget Policies (KUA) that have been approved together with the DRPD of Jakarta Province Province.

Based on Minister of Home Affairs Regulation No. 13 of 2016 article 87, district heads, after drafting PPAS, should submit it to the DPRD at the latest of the second week of July of the on-going budget year to be discussed collectively between the regional government TAPD and DPRD budget body. The planning of PPAS, after being discussed, will be approved into a PPAS at the latest of late July of the on-going budget.

Meanwhile, the case on the discussion of the APBD of Jakarta Province Province in 2017 is that the regional government had drafted the PPAS and submitted it to the DPRD in December the 2nd, 2014 to be discussed by the TAPD and DPRD budget body. However, the schedule issued by the head of Jakarta 
Province Province DPRD for PPAS discussion was December the 20th to 23rd, 2014 (Treatise of DPRD Jakarta Province Hearing).

Procedurally, the process of drafting and mechanism of interaction pattern between the Jakarta Province Provincial Government and DPRD in the formulation of APBD Year 2017 is the planning of KUA and PPAS generally is inseparable from the mechanism of regional budgeting applicable in Jakarta Province Province with the applicable regulations. The formulation of KUA-PPAS Year 2017 is as seen in the figure 2 .

Figure 2. Formulation Process of KUA-PPAS

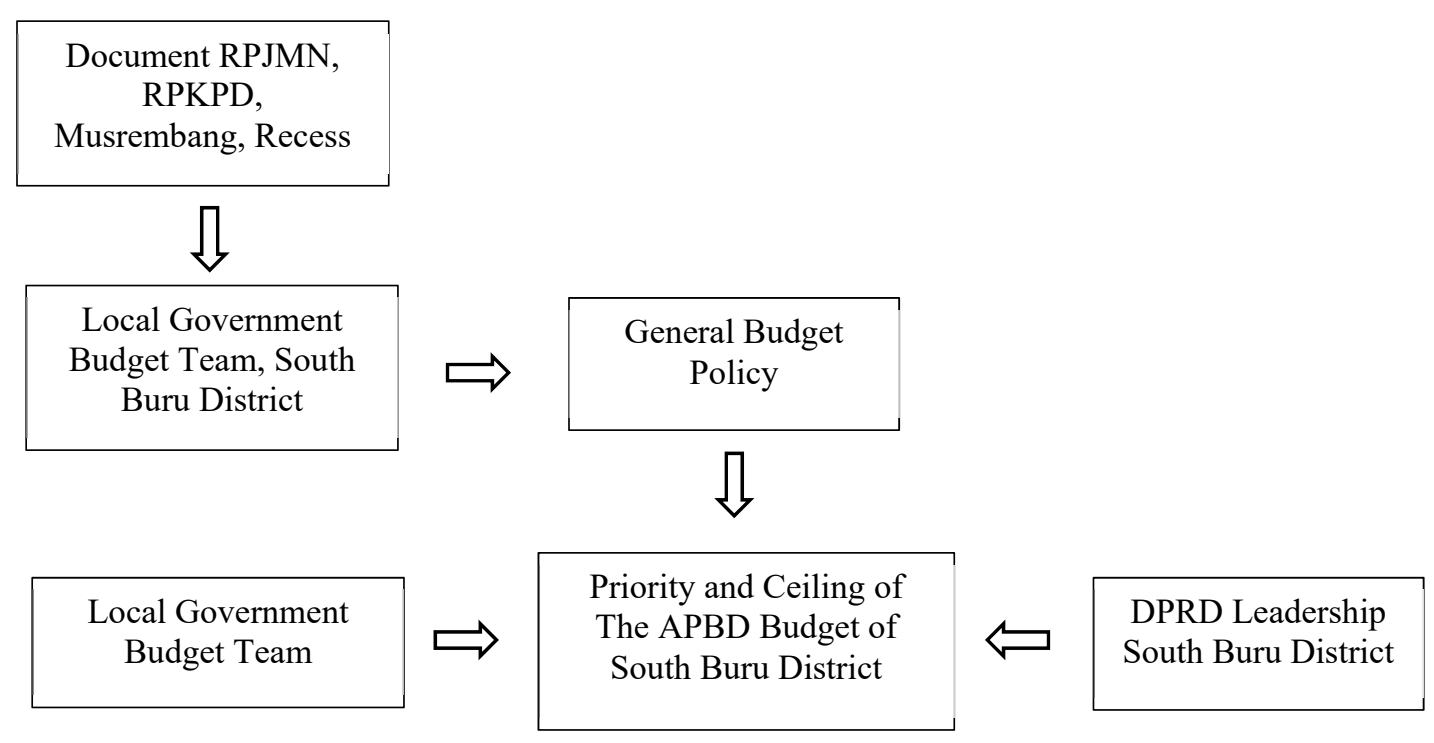

Based on the picture above, the General Budget Policies (KUA) and provisional budget priorities, as well as ceiling, in Jakarta Province Province in Budget Year of 2017 that had been stipulated is the main foundation for regional government to move forward to the next stages, including the stage of the planning of the Regional Revenue and Expenditure Budget Plans (RAPBD) which is entirely regulated by provincial government, in this case, the Regional Government Budget Team (TPAD). Therefore, referring to the KUA-PPAS referendum of agreement, the TPAD of Jakarta Province Province institutionally prepares the planning of circular letter to the regional government regarding the guideline of the drafting of RKA-SKPD as the reference to the SKPD of Jakarta Province Province in planning the RKA-SKPD. After the RKA-SKPD is assessed and evaluated by the Regional Government Budget Team (TPAD), it is formulated 
planning on the 2017 APBD and Draft of Regional Head Regulations regarding the elaboration of Jakarta Province Province APBD of 2017.

Stage 1 (one): Delivering the planning of regional budget policies in Jakarta Province Province must be accompanied by a submission of financial introductory notes of 2017 budget year and planning of regional regulation by the regent. The following conversation will be followed up by the agenda of discussion between the Provincial Government and DPRD of Jakarta Province Province to get a collective approval. Based on the hearing treatise, the plenary session was led directly by the leader of DRPD of Jakarta Province Province.

Stage 2 (two): The level two conversation includes the plenary session of the DRPD of Jakarta Province Province regarding General Overview among Fractions in DPRD toward the Financial Introductory notes and APBD Regional Regulation Planning of 2017 Budget Year which was delivered directly by the Governor.

Stage 3 (three), Plenary session.

Generally, the conversation at the level two includes statements that are contained in the general overview of each fraction. Furthermore, it is continued by the answer of Jakarta Province regent that gave a response to the questions asked, whereas, the technical answers will be stated by each Head of Local Government Working Unit (SKPD) in the level III discussion on commission meeting and or commission combination that was implemented. In the forum, it was presented all SKPD to state the Budget Work Plan (RKA - Rencana Kerja Anggaran) to the Budget Body (Banggar) of DPRD and Regional Government Budget Team (TPAD). The conclusion drawn is that all program proposed by the Regional Government is rationalized in accordance with the public priorities and to minimize the budget. (Treatise of DPRD Jakarta Province 2017 Hearing).

Furthermore, the discussion of the RKA-SKPD, that has not finished yet, at the level of budget body (Banggar) of DPRD was continued in November the 28/29th, 2017. After through a discussion with an intense debate and opposition regarding the priority of the work programs and scales of priorities at the level of budget body (Banggar) of DPRD and at commission level, the budget body of DPRD together with the TAPD of regional government gave a report on the result of commission meeting and followed by budget synchronization either in the type or name of the program or the amount of financing. From the result of the commission report, the regional government conducted an appropriation and improvement in accordance with the result of synchronization, as well as recommendation and responses from the budget body (Banggar) of DPRD. (Treatise of DPRD Jakarta Province 2017 Hearing). 
Based on the Fraction's final view, the plenary session resulted in a decision of the DRPD of Jakarta Province Province Budget Year of 2017 with a No: 01/DPRD/II/2014 regarding Approval of Stipulation of Planning of Jakarta Province Regional Regulations. The stipulation of planning of Jakarta Province Province APBD. After each fraction stated their final view and accepted the Regional Regulations Planning on the APBD of Jakarta Province Province budget year of 2017 to be stipulated into a regional regulation.

The implementation of discussion and stipulation of the planning of Jakarta Province Province APBD of 2017, which was discussion collectively by the Provincial government and DRPD basically refer to the codes of conduct of the Regional People's Representative Council (DPRD) of Jakarta Province Province. The discussion of the planning of the regional regulation of the APBD of Jakarta Province Province basically can result in two possibilities, firstly, collective approval and stipulation by the DPRD and Regional Government through the DRPD plenary session. Secondly, if the DRPD, until past the deadline of one month prior to the budget implementation, does not take a collective decision, then the district heads would make the highest amount of expenditure as the previous budget year's APBD to finance the needs in the on-going budget year, which was formed in the planning of regional heads regulation regarding APBD.

Based on the explanation above, the implementation of e-Budgeting has fulfilled the principles of public sector budget, such as:

a) Authorization by the legislatures: public budget must get an authorization from the legislatures before the executives can spend the budget;

b) Comprehensive: the budget must represent all of the government's revenue and expenditure. Therefore the existence of non-budgetary funds basically violate the principle of comprehensive budget;

c) Budget integrity: all government revenues and expenditures must be collected in the general fund;

d) Nondiscretionary Appropriation: the amount approved by the board of legislatures must be utilized economically, efficiently, and effectively;

e) Periodic: the budget is a periodical process that can be annually or multiannual;

f) Accurate. The Budget estimation is supposed to have a hidden reserve that can be used as bags to contain budget waste and inefficiency, as well as causing revenue underestimation and expenditure overestimation; 
g) Clear: the budget is supposed to be simple, comprehensible to the public, and not confusing; and

h) Known by the public: the budget must be communicated to the open public.

4.2. Factors that Support and Hamper the E-Budgeting Policy Implementation Process in Jakarta Province Government

\subsubsection{Internal Supporting and Obstacle Factors from the Executives and Legis/atures}

Supporting and obstacle factors are factors that come from the interaction pattern between the executives and legislatures within the implementation of eBudgeting related to the discussion of the Regional Revenue and Expenditure Budget (APBD) of 2017. The analysis of relation pattern between the executives and legislatures in the discussion of 2017 Jakarta Province Province APBD can be explained as follows.

(a) In the discussion of 2017 Jakarta Province Province APBD, it was found three executives and legislatures interaction patterns including accommodation, domination, and compromise, yet among the three interaction pattern throughout the entire discussion of budget policy, it was found a more dominant process pattern. The executives and legislatures interaction pattern in the process of discussion at the level of Budget Committee and commission, which expertise is in several SKPDs, tended to be more dominant than the DPRD.

(b) The Executive and Legislatures interaction pattern in the discussion of discussion of 2017 Jakarta Province Province APBD was more dominated by the Decisional Interaction Pattern, which is a pattern of opposition during the formulation of General Budget Policies (KUA) and Provisional Budget Ceiling and Priorities (PPAS), thus, causing a delay in the APBD stipulation, the power interaction pattern happened during the bargaining to exchange the interests of the legislatures to the executives, which was not accommodated in the Budget Work Plan (RKA) of the respective SKPD.

(c) The executives and legislatures power pattern in the discussion of KUA and PPAS in the 2017 APBD discussion was more dominated by the Anticipated Reaction interaction pattern, in which the Jakarta Province Provincial 
Government received the DPRD's interests which became the Recess recommendation to maintain the stability of the 2017 APBD discussion.

(d) In the discussion of Jakarta Province Province RKA, there was an Executive and Legislatures relation pattern that was more dominated by Non Decisional interaction, in which the legislatures refused to discuss the KUA and PPAS because the executives did not submit the document of Budget Work Plan (RKA) from the respective SKPDs.

(e) The interaction pattern of the executives and legislatures in the formulation of the KUA and PPAS showed that the legitimation of regional government is very dominant and the compromising interaction happened more during the budget final discussion, which was discussed by each SKPD in the Jakarta Province Province. Whereas, the domination of DPRD, in this case, was more during the budget stipulation wherein the DPRD authority was stronger due to the function of a supervisory authority and budget function.

(f) The executive and legislatures relation pattern in the process of discussion of General Budget Policies (KUA) and Provisional Budget Ceiling and Priorities (PPAS) in the APBD Planning of Jakarta Province Province of 2017 are still dominated by the political interests, therefore, it caused the prolonged budget discussion that led to the delay of KUA, PPAS, and APBD stipulation.

(g) The Jakarta Province Provincial Government (executives) in the KUA and PPAS discussion generally was coercive, wherein each SKPD has authority in the function of budgeting. Meanwhile, the offensive behavioral relation pattern was showed more during the dialog with the DPRD institutions (Legislatures) to discuss from the formulation of planning up to the formulation of the APBD of Jakarta Province Province

(h) The Provincial Government (Executives) and DPRD (Legislatures) relation pattern was more dominant during the hearing of RAPBD discussion on each commission that was in charge of several SKPDs involved, then, the position of DPRD generally showed a dominant behavior within the budget discussion. The DPRD relation pattern tended to conduct a negotiation, propose the project's interests onto sub-programs in each SKPD. Therefore, in each process of budget discussion that involved DPRD, there was always a public budget negotiation.

(i) The executives and legislatures relation pattern in the discussion of 2017 APBD was very influenced by the personal and political background of the DPRD members in managing the budget of Jakarta Province Province, the interaction pattern influenced positively, either collectively or partially, the 
abilities and comprehension within the implementation of the budget discussion.

The relation pattern above determines whether the e-Budgeting would work efficiently, according to Erwan (2012:85-86), at least, there are six determining factors in a policy implementation process, including:

(a) The quality of the policy itself. The quality comprises many aspects including clarity of objectives, implementor, or person in charge of the implementation, etc.

(b) Adequate policy input, especially the budget. A policy or program will not achieve its objectives or goals without adequate financial support.

(c) The accuracy of the instrument utilized to achieve the policy objectives in terms of services, subsidy, grant, etc.

(d) The capacity of the implementor in terms of organizational structure, human resources support, coordination, supervision, etc.

(e) The characteristics and support of target groups, whether as group or individuals, male or female, educated or uneducated, etc.

(f) The condition of geographic, social, economic, and political environments where the implementation is conducted.

As explained, apparently, the implementation of many government programs have failed to achieve the pre-determined objectives. In fact, many policies had a failure in the stage of implementation as explained by Nugroho (2014): "that the weight of implementation within the policy process is 60 percent, that means, the policy implementation is the heaviest due to the existing problems that were not anticipated in the concept yet occurred in the field".

\subsection{External Obstacle and Supporting Factors}

In the program implementation, it is required an assessment to measure the program's success, therefore, an indicator is necessary for this measurement. Solichin (2008) explained that:

"... in the accomplishment of optimal work target, it must have, acknowledge, and calculate the desired final objectives; the objectives, the issues faced; capital or resources that will be used and its allocation; and the mechanism of monitoring, evaluation, and implementation supervision".

Abdul Wahab (2008:10) argued that the determination of program implementation's success indicator must be principled at five aspects, such as: 
1. The participative principle, the public that will benefit from the planning must also take a role in the process.

2. The sustainability principle, the planning does not only stop on one stage but continues to guarantee sustainable development in the welfare so that there will not be any setback.

3. The holistic principle, the issues within the planning and implementation cannot be seen only from one point of view (sector) but also must be seen from multiple aspects and in the integrity of the concept thoroughly.

4. The adaptive principle, to have a system that can be developed.

5. The pluralistic principle, open and democratic.

Furthermore, those principles must be identified carefully as the foundation to determine the success indicators of the program implementation that is accurate, relevant, and influential to the success of the implementation of policies, programs, or activities.

Abdul Wahab (2008:12) also stated that there is an indicator to measure the success of organizational program implementation deeply, which includes:

(1) Input, every aspect required so that the organization is able to manufacture its products either goods or service, which includes humans, policy information, etc;

(2) Output, something expected to be immediately accomplished from an activity, either physical or non-physical;

(3) Outcomes, all things that reflect the function of activities outcome within an intermediate period of time (direct effect);

(4) Benefit, something related to the final objective of the activities implementation;

(5) Impact, the influence occurred, either positively or negatively, on each indicator level based on the pre-determined assumption.

In the implementation of e-Budgeting of Jakarta Province province of 2017, there were also external support and obstacles, both outside of the executives and legislatures. In the e-Budgeting, the delay in the stipulation of the APBD of Jakarta Province Province became the cause of delay in the implementation of development work that was then affected the parties outside the government.

Based on field findings, which were explained in the previous chapter, there are five factors, such as:

(a) The Factor of Executives' Commitment and Interests;

(b) The Factor of Coordination and Communication between the Executives and Legislatures;

(c) The Factor of Legislatures' Competency and Commitment; 
(d) The Factor of SKPD's Coordination and Competency; and

(e) The Factor of Legislation.

Based on the factors that can explain the reason of delay in the stipulation of the APBD of Jakarta Province Province thus prolonging the process of eBudgeting, it can be drawn solutions to this policy, such as:

(1) Improvement of competency and capacity for the parties involved in the drafting of the APBD through technical guidance or workshop on the drafting of APBD. In the implementation of the technical guidance, it needs to have a combination of participants from the TAPD, Heads of SKPDs, and DRPD members, which is aimed to build an understanding of the mechanism of APBD drafting.

(2) Building a harmonic relationship between the executives and legislatures. The executives, in this case, need to compromise politically with the DPRD members by giving more space in the process of budget allocation so that their aspiration and interests can be accommodated in the APBD. However, it all still needs to be based on public interests.

(3) The central government needs to make stricter regulations toward the parties involved within the APBD drafting, in case the APBD stipulation is delayed, instead of just administrative sanctions.

(4) The regulation on the guideline of APBD drafting issued every year should be reviewed by the central government. The consistency of the regulations on APBD drafting is hoped to ease the parties involved in the APBD drafting.

(5) The regulations related to funding from the upper government should be issued in a timely manner, before the process of APBD drafting.

(6) Transparency within the process of APBD drafting defined by the open process of APBD drafting and the provision of access for public to follow the process of APBD drafting so that it is expected that the inappropriate practices in the budget discussion can be minimized, as well as encouraging the parties involved within the APBD drafting to produce a quality APBD and in accordance with the public's expectations.

(7) It needs to be formulated an analysis of standard expenditure (ASB - analisis standar belanja), therefore, the budget of activities in the RKA-SKPD can be assessed of its equity in accordance with the existing standard (ASB). Besides, the ASB is a requirement for budget planning based on work accomplishment/performance. 


\section{Conclusions}

Based on the discussion of the research findings, it can be formulated several conclusion as follows:

(1) The process of e-Budgeting policy implementation is a part of the budget planning process in APBD, therefore, the implementation process follows the process of APBD budgeting, which is started from the formulation of General Budget Policies and Provisional Budget Ceiling and Priorities (KUAPPAS) up to the stipulation of APBD. The implementation of the e-Budgeting policy is implemented to facilitate effective and efficient APBD drafting. The effectiveness of e-Budgeting policy implementation is influenced by the capacity of its human resources in the mastery of information and telecommunication technology (IT), budgeting politics, and conflicting interests of the executives and legislatures.

(2) The supporting and obstacle factors within the process of e-Budgeting policy implementation include the factors of executives' commitment and interests, coordination and communication between the executives and legislatures, legislatures' competency and commitment, coordination and competency of OPD, as well as legislation factor. Additionally, the addition and subtraction of activities and budget allocation by the executives within the RAPBD discussion, besides the lack of preparation in the planning during the initial stage, there are also attempts to prioritize interests. Meanwhile, the issues of the SKPDs in drafting the budget based on work accomplishment as written in the RKA-SKPD are actually still related to the SKPD's competency.

The recommendations that can be formulated from these research findings from multiple parties including local farmers, regional government, and other parties are:

(1) The improvement of competency and capacity for the parties involved in APBD drafting through technical guidance or workshop on APBD drafting and especially the use of e-budgeting. In the implementation of the technical guidance, it needs to have a combination of participants from the TAPD, Heads of OPD, and experts from DRPD members. This is aimed to build an understanding of the mechanism of APBD drafting.;

(2) building a harmonic relationship between the executives and legislatures through sustainable communication and coordination so that it eases the "political compromise" in the process of APBD drafting; by giving more space in the process of budget allocation, thus, their aspiration and 
interests can be accommodated in the APBD, however, it all still needs to be based on public interests;

(3) The central government needs to make stricter regulations toward the parties involved within the APBD drafting, therefore, if the APBD is stipulated and passed late, there will be not only administrative sanctions but also others, such as subtraction of special fund allocation, etc.

(4) the regulation on the guideline of APBD drafting issued every year should be reviewed by the central government so that there will be consistency in the regulations of APBD drafting, and it is to ease the parties involved in the e-Budgeting-based APBD drafting

(5) the regulations related to funding from the upper government should be issued in a timely manner and not beyond the deadline of the process of APBD drafting, therefore, it would not cause changes in the input of budget data into the e-Budgeting.

(6) transparency within the process of APBD drafting through e-Budgeting must open an access for public to follow the process of APBD drafting so that it is expected that the inappropriate practices in the budget discussion can be minimized, as well as encouraging the parties involved within the APBD drafting to produce a quality APBD and in accordance with the public's expectations

(7) It needs to be formulated an analysis of standard expenditure (ASB analisis standar belanja), therefore, the budget of activities in the RKASKPD can be assessed of its equity in accordance with the existing standard (ASB). Besides, the ASB is a requirement for budget planning based on work accomplishment/performance.

\section{References}

[1]. Abdul Wahab, Solichin, (1998). Analisis Kebijakan Publik: Teori dan Aplikasi. Malang: FIA Unibraw Malang.

[2]. Abdul Wahab, Solichin, (1997a). Analisis Kebijaksanaan: Dari Formulasi ke Implementasi Kebijaksanaan Negara. Jakarta: Bumi Aksara.

[3]. Abdul Wahab, Solichin, (1997b). Evaluasi Kebijakan Publik. Malang: IKIP Malang Press.

[4]. Abdul Wahab, Solichin, (1999). Ekonomi Politik Pembangunan, Bisnis Indonesia Era Orde Baru dan di Tengah Krisis moneter, Danar Wijaya, Brawijaya University Press.

[5]. Blog Uangteman, (2016). "Transparansi Anggaran Melalui e-Budgeting". Diakses melalui https://uangteman.com/blog. 28 Januari 2016.

[6]. Caiden, Derald, (1982). Public Administration (2nd ed., Palisaces Publisher: California.

[7]. Chaniago, Muhardi Achmad, (2015). "Akuntansi Sektor Publik: Anggaran Sektor Publik". Diakses melalui http://tintamuhardi.blogspot.co.id/2015/03, tanggal 3 Juni 2017.

[8]. Erianto, Dwi, (2015). "Kisruh APBD Jakarta Province”. Dalam Kronologi, Balitbang Kompas, 19 Maret 2015. 
[9]. Miles, Matthew B.; dan Huberrman, A. Michael; dan Saldana, Johnny; (2014). Qualitative Data Analysis: A Methods Sourcebook. Singapore: SAGE Publications Inc.

[10]. Mishra, S.C., Chowdhury, A., Islam, I., Suharyono, W.I., Tadjoeddin, M.Z. dan Irawan, P.B., (2001). Indonesia n Human Development Report 2001: Towards a new consensus democracy and human development in indonesia, BPS, Bappenas, UNDP: Jakarta.

[11]. Moleong, Lexy J., (1996). Metode Penelitian Kualitatif. Jakarta: PT. Rajawali PersNugroho, Riant, 2014. Public Policy: Teori, Manajemen, Dinamika, Analisis, Konvergensi, dan Kimia Kebijakan. Jakarta: PT. Elex Media Komputindo.

[12]. Kuncoro, Mudrajad, (2004). Otonomi dan Pembangunan Daerah, Reformasi, Perencanaan, Strategi, dan Peluang, Penerbit Erlangg: Jakarta.

[13]. Islamy, M. Irfan, (1992). Prinsip-prinsip Perumusan Kebijaksanaan Negara, Bina Aksara, Jakarta.

[14]. Okezone News, (2015). “E-Budgeting Jakarta Province Belum Maksimal”. Diakses melalui http://www.okezone.com. 27 Januari 2016.

[15]. Sarudjajang, (1992). Pemerintah Daerah Diberbagai Negara Sebuah Pengantar. Pustaka Sinar Harapan: Jakarta. 